\title{
PENTINGNYA PENGUASAAN KONSEP KESELAMATAN DAN KESEHATAN KERJA (K3) DALAM MENDUKUNG KINERJA CALON LULUSAN PENDIDIKAN KEJURUAN DI DUNIA KERJA
}

\author{
Ni Komang Widyawati \\ Jurusan Teknologi Industri \\ Universitas Pendidikan Ganesha \\ Singaraja, Indonesia \\ email: widyawati@undiksha.ac.id
}

\begin{abstract}
Abstrak
Artikel ini bertujuan untuk membahas pentingnya penguasaan konsep keselamatan dan kesehatan kerja (K3) dalam mendukung kinerja calon lulusan pendidikan kejuruan di dunia kerja. SMK sebagai pelaksana pendidikan kejuruan memiliki banyak program keahliaian yang menyesuaikan dengan kebutuhan dunia kerja yang ada. Dalam dunia kerja, konsep keselamatan dan kesehatan kerja (K3) merupakan konsep yang penting diterapkan oleh setiap tenaga kerja disamping skill sesuai keahlian masing-masing. Metode pengumpulan data yang digunakan dalam artikel ini adalah kepustakaan. Artikel yang diulas dan direview terdiri atas lima buah artikel dengan pokok bahasan yang sesuai dengan kata kunci pokok bahasan artikel ini yaitu mengenai kesehatan dan keselamatan kerja (K3). Hasil penelitian yang dipaparkan dalam kelima artikel hasil penelitian tersebut menunjukan bahwa konsep keselamatan dan kesehatan kerja (K3) berpengaruh positif terhadap kinerja perusahaan maupun tenaga kerja yang terlibat. Oleh karena itu penguasaan konsep K3 penting ditanamkan sejak mengenyam pendidikan di jenjang SMK karena pendidikan kejuruan merupakan lembaga yang mencetak lulusan yang dipersiapkan untuk terjun di dunia kerja. K3 dapat dimuat dalam kurikulum pendidikan kejuruan agar konsep ini semakin dipahami oleh peserta didik di jenjang pendidikan kejuruan (SMK) agar kemampuan yang didapatkan sesuai dengan kebutuhan dan permintaan pasar/ dunia kerja.
\end{abstract}

\begin{abstract}
This article aims to discuss the importance of mastering the concept of occupational safety and health in supporting the performance of prospective vocational education graduates in the world of work. SMK as a vocational education provider has many expertise programs that adapt to the needs of the existing work world. In the world of work, the concept of occupational safety and health is an important concept applied by every worker in addition to skills according to their respective expertise. The data collection method used in this article is literature. The articles reviewed and reviewed consist of five articles with subjects that match the keywords of the subject matter of this article, namely occupational health and safety. The research results presented in the five articles of the research results indicate that the concept of occupational safety and health has a positive effect on the performance of the company and the workforce involved. Therefore mastery of that concept is important to instill since receiving education at the SMK level because vocational education is an institution that produces graduates who are prepared to enter the world of work. Occupational safety and health can be included in the vocational education curriculum so that this concept is increasingly understood by students at the vocational education level so that the abilities obtained are in accordance with the needs and demands of the market / world of work.
\end{abstract}




\section{PENDAHULUAN}

Pendidikan

kejuruan

merupakan salah satu pilihan jenjang pendidikan menengah yang dilaksanakan setelah jenjang pendidikan sekolah menengah pertama (SMP). Menurut UU No 20 Tahun 2003, pendidikan kejuruan merupakan pendidikan menengah yang mempersiapkan peserta didik terutama untuk bekerja dalam bidang tertentu. Dengan kata lain, pendidikan menengah kejuruan adalah pendidikan pada jenjang pendidikan menengah yang mengutamakan pengembangan kemampuan siswa untuk melaksanakan jenis pekerjaan tertentu. Pendidikan menengah kejuruan mengutamakan penyiapan siswa untuk memasuki lapangan kerja serta mengembangkan sikap professional. Sesuai dengan pengertian tersebut, pendidikan kejuruan dapat menjadi wadah dalam mendidik siswa untuk menguasai kemampuan di bidang tertentu sesuai jurusan yang dipilih dalam pendidikan kejuruan.

Berdasarkan UU No 20 Tahun 2003, pendidikan kejuruan memiliki beberapa tujuan yang terdiri dari tujuan umum dan tujuan khusus. Tujuan umum pendidikan menengah kejuruan adalah : (a) meningkatkan keimanan dan ketakwaan peserta didik kepada Tuhan Yang Maha Esa; (b) mengembangkan potensi peserta didik agar menjadi warga Negara yang berakhlak mulia, sehat, berilmu, cakap, kreatif, mandiri, demokratis dan bertanggung jawab; (c) mengembangkan potensi peserta didik agar memiliki wawasan kebangsaan, memahami dan menghargai keanekaragaman budaya bangsa Indonesia; dan (d) mengembangkan potensi peserta didik agar memiliki kepedulian terhadap lingkungan hidup dengan secara aktif turut memelihara dan melestarikan lingkungan hidup, serta memanfaatkan sumber daya alam dengan efektif dan efisien. Tujuan khusus pendidikan menengah kejuruan adalah sebagai berikut: (a) menyiapkan peserta didik agar menjadi manusia produktif, mampu bekerja mandiri, mengisi lowongan pekerjaan yang ada sebagai tenaga kerja tingkat menengah sesuai dengan kompetensi dalam program keahlian yang dipilihnya; (b) menyiapkan peserta didik agar mampu memilih karir, ulet dan gigih dalam berkompetensi, beradaptasi di lingkungan kerja dan mengembangkan sikap profesional dalam bidang keahlian yang diminatinya; (c) membekali peserta didik dengan ilmu pengetahuan, teknologi dan seni agar mampu mengembangkan diri di kemudian hari baik secara mandiri maupun melalui jenjang pendidikan yang lebih tinggi; dan (d) membekali peserta didik dengan kompetensi kompetensi yang sesuai dengan program keahlian yang dipilih. Oleh karena itu, pelaksanaan pendidikan kejuruan di satuan pendidikan berpatokan pada tujuan tersebut.

SMK sebagai pelaksana pendidikan kejuruan memiliki banyak program keahliaian yang dilaksanakan di SMK menyesuaikan dengan kebutuhan dunia kerja yang ada. Program keahlian pada jenjang SMK juga menyesuaikan pada permintaan masyarakat dan pasar. Peserta didik dapat memilih bidang keahlian yang diminati di SMK. Kurikulum SMK dibuat agar peserta didik siap untuk langsung bekerja di dunia kerja. Muatan kurikulum yang ada di SMK disusun sedemikian rupa sesuai dengan kebutuhan dunia kerja yang ada. Hal ini dilakukan agar peserta didik tidak mengalami kesulitan yang berarti ketika masuk di dunia kerja. Setelah lulus dari jenjang pendidikan kejuruan, peserta didik diharapkan menjadi praktisi yang baik sesuai program keahlian yang dipilih pada saat mengenyam pendidikan 
kejuruan. Dengan masa studi tiga atau empat tahun, lulusan SMK diharapkan mampu untuk bekerja sesuai dengan keahlian yang telah ditekuni.

Pendidikan kejuruan dirancang agar lulusan yang dihasilkan dapat langsung bekerja. Oleh karena itu, skill dan kompetensi yang diasah harus sesuai dengan kebutuhan dunia kerja. Selain kemampuan utama yang sesuai dengan program keahlian, kemampuan-kemampuan yang mendukung kinerja calon lulusan pendidikan kejuruan di dunia kerja harus diasah. Salah satu kemampuan yang menjadi bagian penting pada saat menjadi tenaga kerja pada dunia kerja adalah penguasaan konsep keselamatan dan kesehatan kerja (K3). Sebagai calon praktisi yang akan terjun di dunia kerja, konsep keselamatan dan kesehatan kerja (K3) harus dipahami dan diimplementasikan sesuai dengan ketentuan dari penyedia pekerjaan.

Konsep keselamatan dan kesehatan kerja (K3) merupakan konsep yang penting dalam menjalankan prosedur kerja. Keselamatan dan kesehatan kerja (K3) merupakan suatu pemikiran dan upaya untuk menjamin keutuhan dan kesempurnaan baik jasmani dan rohani yang bertujuan untuk menjaga keamanan dan kenyamanan tenaga kerja agar tercapainya ketahanan fisik, daya kerja, dan tingkat kesehatan yang tinggi (Hasibuan dkk, 2020). Jika telah diimplementasikan, konsep K3 akan memberikan dampak positif terhadap produktivitas kerja yang dilakukan dan dapat meningkatkan kinerja setiap tenaga kerja ke arah yang lebih baik. Resiko kecelakaan kerja yang dapat merugikan tenaga kerja dan mempengaruhi produktivitas kerja dapat dimimalkan jika telah mengimplementasikan konsep K3 dengan baik (Fitri, 2016).
Pentingnya

pengimplementasian keselamatan dan kesehatan kerja (K3) di dunia kerja dapat diulas dan dikaji melalui riset atau penelitian yang telah dilakukan sebelumnya. Dengan adanya pengkajian pentingnya $\mathrm{K} 3 \mathrm{di}$ dalam dunia kerja, maka pendidikan kejuruan yang merupakan jenjang pendidikan yang mempersiapkan calon lulusan yang akan menjadi praktisi di dunia kerja harus dapat menanamkan konsep K3 di dalam proses pendidikan sesuai dengan program keahlian masing-masing. Dengan demikian, peran pendidikan kejuruan sebagai pencetak lulusan yang kompeten akan menjadi semakin relevan dengan situasi dan s kebutuhan dunia kerja.

\section{METODE}

Metode pengumpulan data yang digunakan adalah metode kepustakaan. Metode kepustakaan adalah serangkaian kegiatan yang berkenaan dengan metode pengumpulan data pustaka, membaca dan mencatat serta mengolah bahan penelitian (Zed, 2004). Review artikel hasil penelitian yang relevan dapat mendukung pembahasan dalam artikel ini sehingga dapat ditarik kesimpulan sesuai poin-poin yang dibahas dari semua artikel hasil penelitian yang telah diulas dan di direview. Dalam artikel ini, mengulas dan mereview lima buah artikel dengan pokok bahasan yang sesuai dengan kata kunci pokok bahasan artikel ini yaitu mengenai kesehatan dan keselamatan kerja (K3). Berikut adalah artikel yang direview sebagai berikut. Pertama, penelitian yang dilakukan oleh Kaligis, dkk (2013) dengan judul Pengaruh Implementasi Program Keselamatan dan Kesehatan Kerja (K3) Terhadap Produktivitas Kerja. Kedua, penelitian yang dilakukan oleh Estiawan (2012) dengan judul Analisis Sistem Manajemen 
Keselamatan dan Kesehatan Kerja (SMK3) Terhadap Kepuasan Kerja Karyawan, Studi Pada PT. PJB. UP Brantas (Perusahaan yang Bergerak Pada Bidan Pemeliharaan dan Pembangkitan Listrik). Ketiga, penelitian yang dilakukan oleh Dewi dan Novadjadja (2019) dengan judul Pengaruh Implementasi Program Keselamatan dan Kesehatan Kerja (K3) Terhadap Kinerja Karyawan (Studi Pada Pt. Sinar Sosro Kpb Gianyar Bali). Keempat, penelitian yang dilakukan oleh Nurhidayanti (2017) dengan judul Pengaruh Pelaksanaan Keselamatan dan Kesehatan Kerja (K3) Terhadap Kepuasan Kerja Perawat (Studi Kasus Rumah Sakit Umum Daerah (RSUD) Arifin Achmad Pekanbaru). Kelima, penelitian yang dilakukan oleh Sinuhaji (2019) dengan judul Pengaruh Keselamatan dan Kesehatan Kerja (K3) terhadap Produktivitas Kerja Karyawan. Hasil penelitian yang telah terdapat dalam artikel-artikel tersebut akan dapat memberikan gambaran mengenai pentingnya penguasaan konsep keselamatan dan kesehatan kerja (K3) dalam mendukung kinerja calon lulusan pendidikan kejuruan di dunia kerja.

\section{HASIL DAN PEMBAHASAN}

Penelitian yang relevan mengenai konsep keselamatan dan kesehatan kerja (K3) dapat dirangkum dalam menarik kesimpulan mengenai pentingnya penguasaan konsep keselamatan dan kesehatan kerja (K3) dalam mendukung kinerja calon lulusan pendidikan kejuruan di dunia kerja. Berikut adalah rangkuman dari hasil penelitian yang telah dilakukan sebelumnya mengenai konsep keselamatan dan kesehatan kerja (K3) di dunia kerja, mulai dari implementasinya dan dampaknya terhadap kinerja perusahaan maupun dampak kepada tenaga kerja yang terlibat dalam perusahaan. Rangkuman tersebut diperoleh dari kesimpulan dari setiap penelitian yang telah dilakukan tersebut.

Penelitian yang dilakukan oleh Kaligis, dkk (2013) dengan judul Pengaruh Implementasi Program Keselamatan dan Kesehatan Kerja (K3) Terhadap Produktivitas Kerja memuat dua kesimpulan sebagai berikut. 1) Implementasi program keselamatan dan kesehatan kerja akan memberikan pengaruh yang signifikan terhadap peningkatan produktivitas kerja jika keduanya diterapkan serentak. Hal ini telah di buktikan melalui hasil pengujian, yaitu pegujian parsial / individual dan simultan serentak. Dimana dalam pengujian parsial dengan distribusi $t$ memberikan hasil tb1 $=0,152$ berada diantara $-2,763$ dan $+2,763$ dan $\mathrm{tb} 2=0,232$ berada diantara 2,763 dan $+2,763$ keduanya tidak memberikan pengaruh yang signifikan (HO diterima) karena dipisahkan. Sedangkan pada uji simultan dengan distribusi $F$ memberikan hasil $F$ hitung $=15,311$ $\geq 3,354$ ( $\mathrm{HO}$ ditolak) terdapat pengaruh yang signifikan. 2) Implementasi program keselamatan dan kesehatan kerja pada pelaksanaan proyek pembangunan PT. Trakindo Utama Balikpapan Facility Upgrade memiliki hubungan yang erat dengan peningkatan produktivitas kerja, dimana telah diperoleh hasil dari analisis korelasi berganda $R=0,729$. Angka ini mendekati angka 1 yang artinya terdapat hubungan yang erat.

Penelitian yang dilakukan oleh Estiawan (2012) dengan judul Analisis Sistem Manajemen Keselamatan dan Kesehatan Kerja (SMK3) Terhadap Kepuasan Kerja Karyawan, Studi Pada PT. PJB. UP Brantas (Perusahaan yang Bergerak Pada Bidan Pemeliharaan dan Pembangkitan Listrik) memuat tiga kesimpulan sebagai berikut. 1) hasil penelitian ini menunjukan bahwa 
variabel Sistem Manajemen Keselamatan dan Kesehatan Kerja (SMK3) yang terdiri dari variabel komitmen dan kebijakan manajemen terhadap K3, perncanaan K3, implementasi K3, pemeriksaan K3, dan tinjauan manajemen dan peningkatan SMK3 berpengaruh bersama-sama terhadap kepuasan kerja karyawan. Dengan kata lain semakin baik SMK3 maka semakin baik pula faktor kepuasan kerja karyawan (hipotesis pertama diterima). 2) hasil penelitian ini menunjukan bahwa variabel yang berpengaruh secara parsial terhadap kepuasan kerja karyawan PT.PJB UP Brantas antara lain variabel komitmen dan kebijakan manajemen terhadap K3, implementasi K3, dan tinjauan manajemen dan peningkatan SMK3, sedangkan variabel perencanaan $\mathrm{K} 3$ dan pemeriksaan K3 merupakan variabel yang tidak berpengaruh secara parsial. Dengan kata lain semakin baik perencanaan K3 dan pemeriksaan K3 maka tidak akan mengakibatkan peningkatan kepuasan kerja karyawan. 3) Hasil penelitian ini menunjukan variabel dominan adalah variabel implementasi K3. Hal ini menunjukkan bahwa hipotesis ketiga (H3) yaitu komitmen dan kebijakan manajemen terhadap K3 adalah variabel dominan yang berpengaruh terhadap kepuasan kerja karyawan ditolak.

Penelitian yang dilakukan oleh Dewi dan Novadjadja (2019) dengan judul Pengaruh Implementasi Program Keselamatan dan Kesehatan Kerja (K3) Terhadap Kinerja Karyawan (Studi Pada PT. Sinar Sosro KPB Gianyar Bali) memuat kesimpulan sebagai berikut. 1) Pengimplementasian prograM Keselamatan dan Kesehatan Kerja (K3) Karyawan di perusahaan PT. Sinar Sosro KPB Gianyar Bali, telah sesuai dengan yang diinginkan perusahaan beserta jajaran didalamnya seperti para pimpinan, para karyawan, pemerintah, dan juga masyarakat, dalam menciptakan suasana kerja yang sehat, aman, nyaman, harmonis, dan produktif, serta dapat mencapai serta melampaui zero accident \& incident. 2) Kinerja karyawan di perusahaan PT. Sinar Sosro KPB Gianyar Bali, tergolong baik dan menunjukkan pencapaian kinerja yang stabil sesuai dengan yang diinginkan perusahaan dalam pencapaian target dari hasil produksi yang dilakukan untuk pemenuhan kebutuhan pendistribusian yang akan dilakukan ke berbagai wilayah Bali Nusra. 3) Pengaruh atau dampak yang ditimbulkan dari pengimplementasian program $\mathrm{K} 3$ terhadap kinerja karyawan di perusahaan PT. Sinar Sosro KPB Gianyar Bali, membawa dampak dan pengaruh yang besar dan positif, serta mempunyai hubungan keterkaitan dan saling mempengaruhi satu sama lainnya dalam penerapan maupun pelaksanaannya.

Penelitian yang dilakukan oleh Nurhidayanti (2017) dengan judul Pengaruh Pelaksanaan Keselamatan dan Kesehatan Kerja (K3) Terhadap Kepuasan Kerja Perawat (Studi Kasus Rumah Sakit Umum Daerah (RSUD) Arifin Achmad Pekanbaru) memuat kesimpulan sebagai berikut. 1) Hasil penelitian ini menunjukan variabel keselamatan dan kesehatan kerja (K3) Rumah Sakit Umum Daerah Arifin Achmad Pekanbaru berada pada kategori tinggi, yang terdiri indikator keadaan dan kondisi perawat, lingkungan kerja, perlindungan kerja, tempat kerja, dan mesin dan peralatan kerja. Dimana tinggi diartikan sebagai keselamatan dan kesehatan kerja baik untuk diterapkan di RSUD Arifin Achmad Pekanbaru agar mempengaruhi kepuasan kerja perawat dalam bekerja. 2) Hasil 
penelitian ini menunjukan variabel kepuasan kerja perawat Rumah Sakit Umum Daerah Arifin Achmad Pekanbaru berada pada kategori cukup tinggi dilihat dari indikator prestasi kerja perawat, tingkat kemangkiran kerja perawat, keinginan pindah perawat dan lama bekerja perawat. Dimana kategori cukup tinggi diartikan sebagai kepuasan perawat dalam bekerja sudah cukup baik dimana antara pekerjaan yang diberikan dengan hasil mereka berikan sudah cukup baik. 3) Berdasarkan hasil perhitungan regresi linier sedehana, uji $R$, dan uji $t$ dengan program SPSS dapat diketahui bahwa keselamatan dan kesehatan berpengaruh positif terhadap kepuasan kerja peraat kerja (K3) pada Rumah Sakit Umum Daerah Pekanbaru.

Penelitian yang dilakukan oleh Sinuhaji (2019) dengan judul Pengaruh Keselamatan dan Kesehatan Kerja (K3) terhadap Produktivitas Kerja Karyawan memuat kesimpulan bahwa keselamatan dan kesehatan kerja berpengaruh positif dan signifikan terhadap produktivitas kerja karyawan bagian produksi pada PT. $X$ di Batam.

Dari hasil penelitian yang telah dibahas di atas, dapat dilihat bahwa konsep keselamatan dan kesehatan kerja (K3) berpengaruh positif terhadap kinerja perusahaan maupun tenaga kerja yang terlibat. Implementasi dan penguasaan konsep K3 yang dilakukan oleh tenaga kerja secara tidak langsung merupakan kebutuhan dari perusahaan disamping keahlian yang telah dikuasai oleh setiap tenaga kerja sesuai bidangnya. Dengan demikian, konsep K3 penting untuk dikuasai oleh calon tenaga kerja sebelum terjun ke dunia kerja.

Pendidikan kejuruan sebagai jenjang pendidikan yang bertujuan untuk menyiapkan calon lulusannya untuk terjun di dunia kerja harus dapat mengajarkan dan melatih peserta didiknya agar menguasai konsep K3. Hal ini dapat dimulai dengan diintegrasikanya pengetahuan dan keterampilan mengenai K3 dalam kurikulum pendidikan kejuruan. Mengingat pentingnya $\mathrm{K} 3$ di dunia kerja, penguasaan konsep-konsep K3 oleh siswa harus ditanamkan dengan serius dalam jenjang pendidikan kejuruan. Dengan hal tersebut, calon lulusan akan memiliki kemampuan yang semakin baik dan semakin relevan dengan kebutuhan perusahaan di dunia kerja. Lulusan yang baik dan sesuai dengan kebutuhan akan semakin cepat diserap oleh perusahaan di dunia kerja. Semakin tinggi penyerapan lulusan SMK di dunia kerja, maka akan citra pendidikan kejuruan akan semakin baik dan dapat menjadi pilihan masyarakat.

\section{SIMPULAN DAN SARAN}

Berdasarkan pembahasan di atas dapat disimpulkan bahwa pendidikan menengah kejuruan adalah pendidikan pada jenjang pendidikan menengah yang mengutamakan pengembangan kemampuan siswa untuk melaksanakan jenis pekerjaan tertentu. SMK sebagai pelaksana pendidikan kejuruan memiliki banyak program keahliaian yang menyesuaikan dengan kebutuhan dunia kerja yang ada. Program keahlian pada jenjang SMK juga menyesuaikan pada permintaan masyarakat dan pasar. Dalam dunia kerja, konsep keselamatan dan kesehatan kerja (K3) merupakan konsep yang penting diterapkan oleh setiap tenaga kerja disamping skill sesuai keahlian masing-masing. Dari hasil penelitian yang telah dipaparkan, konsep keselamatan dan kesehatan kerja (K3) berpengaruh positif terhadap kinerja 
perusahaan maupun tenaga kerja yang terlibat. Implementasi dan penguasaan konsep K3 yang dilakukan oleh tenaga kerja secara tidak langsung merupakan kebutuhan dari perusahaan. Oleh karena itu penguasaan konsep K3 penting ditanamkan sejak mengenyam pendidikan di jenjang SMK karena pendidikan kejuruan merupakan lembaga yang mencetak lulusan yang dipersiapkan untuk terjun di dunia kerja. K3 dapat dimuat dalam kurikulum pendidikan kejuruan agar konsep ini semakin dipahami oleh peserta didik di jenjang pendidikan kejuruan (SMK) agar kemampuan yang didapatkan sesuai dengan kebutuhan dan permintaan pasar/ dunia kerja.

Adapun saran yang dapat diuraikan dalam artikel ini yaitu sebaiknya konsep keselamatan dan kesehatan kerja (K3) semakin diperhatikan dalam pendidikan kejuruan mengingat manfaat dan dampak positifnya di dalam dunia kerja.

\section{DAFTAR PUSTAKA}

Dewi, N.N.A.P dan L.H. Novadjaja. 2019. Pengaruh Implementasi Program Keselamatan dan Kesehatan Kerja (K3) Terhadap Kinerja Karyawan (Studi Pada Pt. Sinar Sosro Kpb Gianyar Bali). Jurnal

Estiawan, F.S. 2012. Analisis Sistem Manajemen Keselamatan dan Kesehatan Kerja (SMK3) Terhadap Kepuasan Kerja Karyawan, Studi Pada PT. PJB. UP Brantas (Perusahaan yang Bergerak Pada Bidang Pemeliharaan dan Pembangkitan Listrik). Jurnal

Fitri, S.N. 2016. Implementasi Kesehatan dan Keselamatan Kerja Karyawan Perusahaan Dalam Menghadapi MEA
2016. Jurnal Spread, Vol. 6, No. 1 (hlm 53-62)

Hasibuan, A., dkk. 2020. Teknik Keselamatan dan Kesehatan Kerja. Jakarta: Yayasan Kita Menulis

Kaligis, R.S.V dkk. 2013. Pengaruh Implementasi Program Keselamatan dan Kesehatan Kerja (K3) Terhadap Produktivitas Kerja. Jurnal Sipil Statik, Vol. 1, No. 3 (hlm 219-225)

Nurhidayanti, D. 2017. Pengaruh Pelaksanaan Keselamatan dan Kesehatan Kerja (K3) Terhadap Kepuasan Kerja Perawat (Studi Kasus Rumah Sakit Umum Daerah (RSUD) Arifin Achmad Pekanbaru). Jurnal IImu Administrasi, Vol. 4, No. 1 (hlm 1-10)

Pemerintah Indonesia. 2003. Undang Undang No 20 Tahun 2003. Jakarta

Sinuhaji, E. 2019.Pengaruh Keselamatan dan Kesehatan Kerja (K3) terhadap Produktivitas Kerja Karyawan. Jurnal IImu Manajemen, Vol. 7, No.2 (hlm 11-15)

Zed, Mestika. 2004. Metode Penelitian Kepustakaan. Jakarta: Yayasan Obor Indonesia 